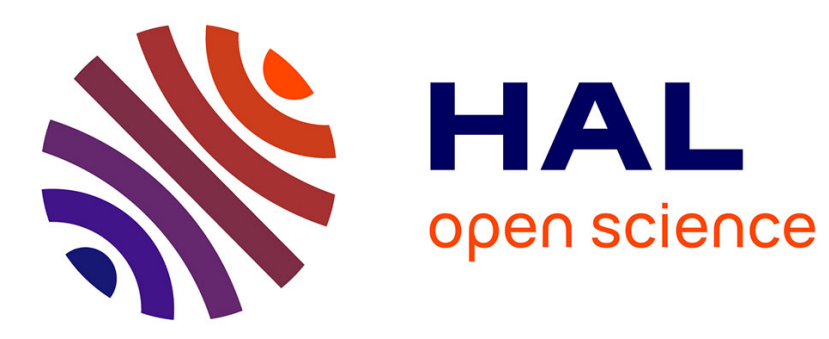

\title{
Metabolic changes and tissue responses to selection on residual feed intake in growing pigs
}

Thierry T. Le Naou, Nathalie Le Floc'H, Isabelle Louveau, Hélène Gilbert, Florence Gondret

\section{- To cite this version:}

Thierry T. Le Naou, Nathalie Le Floc'H, Isabelle Louveau, Hélène Gilbert, Florence Gondret. Metabolic changes and tissue responses to selection on residual feed intake in growing pigs. Journal of Animal Science, 2012, 90 (13), pp.4771-4780. 10.2527/jas.2012-5226 . hal-01001044

\section{HAL Id: hal-01001044 \\ https://hal.science/hal-01001044}

Submitted on 29 May 2020

HAL is a multi-disciplinary open access archive for the deposit and dissemination of scientific research documents, whether they are published or not. The documents may come from teaching and research institutions in France or abroad, or from public or private research centers.
L'archive ouverte pluridisciplinaire HAL, est destinée au dépôt et à la diffusion de documents scientifiques de niveau recherche, publiés ou non, émanant des établissements d'enseignement et de recherche français ou étrangers, des laboratoires publics ou privés. 


\section{JOURNAL OF ANIMAL SCIENCE \\ The Premier Journal and Leading Source of New Knowledge and Perspective in Animal Science}

Metabolic changes and tissue responses to selection on residual feed intake in growing pigs

T. Le Naou, N. Le Floc'h, I. Louveau, H. Gilbert and F. Gondret

J ANIM SCI 2012, 90:4771-4780.

doi: 10.2527/jas.2012-5226 originally published online August 7, 2012

The online version of this article, along with updated information and services, is located on the World Wide Web at:

http://www.journalofanimalscience.org/content/90/13/4771

www.asas.org 


\title{
Metabolic changes and tissue responses to selection on residual feed intake in growing pigs 1,2
}

\author{
T. Le Naou, $* \dagger$ N. Le Floc’h, $* \dagger$ I. Louveau, $* \dagger$ H. Gilbert, $\$ \S$ and F. Gondret $* \dagger 3$ \\ *INRA, UMR1348 PEGASE, F-35590 Saint-Gilles, France; †Agrocampus Ouest, UMR1348 PEGASE, F-35000 Rennes, France; \\ †INRA, UMR444 LGC, F-31326 Castanet-Tolosan, France; and §INRA, UMR1313 GABI, F-78352 Jouy-en-Josas, France
}

\begin{abstract}
Previous selection experiments using residual feed intake (RFI) to select pigs with a high feed efficiency have reported that a low RFI was associated with a reduced body fat content and a greater muscle glycogen content. In the current study, growing Large White female piglets from 2 lines divergently selected for RFI were used to determine the changes in energy and protein metabolisms in key tissues and their cross talks in response to selection. Pigs of low RFI $\left(\mathrm{RFI}^{-} ; \mathrm{n}=26\right)$ or high RFI $\left(\mathrm{RFI}^{+} ; \mathrm{n}=36\right)$ selection lines were offered free access to feed during postweaning and growing periods. Pigs of each line were then slaughtered at $19 \mathrm{~kg}(\mathrm{n}=8$ per line) or $115 \mathrm{~kg} \mathrm{BW}(\mathrm{n}=14$ to 18 per line). A third group of pigs of the $\mathrm{RFI}^{+}$line was offered feed at the same level per metabolic BW (BW0.60) as RFI- pigs (group RFI+R, $n=14$ ). Regardless of the growth period considered, G:F was less in $\mathrm{RFI}^{+}$pigs than in $\mathrm{RFI}^{-}$pigs. At $19 \mathrm{~kg} \mathrm{BW}, \mathrm{RFI}^{+}$and $\mathrm{RFI}^{-}$pigs had a similar body composition and tissue lipid content. The fractional rate of protein synthesis and proteasome activity were decreased $(P<0.090)$ in the livers of $\mathrm{RFI}^{+}$pigs compared with $\mathrm{RFI}^{-}$pigs whereas activities of energy catabolic
\end{abstract}

enzymes did not differ in the liver and LM samples. Plasma insulin was conversely greater $(P=0.049)$ in $\mathrm{RFI}^{+}$pigs at this stage. At $115 \mathrm{~kg} \mathrm{BW}$, enzyme activities of protein catabolism in the liver and in the LM did not differ $(P>0.10)$ between $\mathrm{RFI}^{+}$pigs and $\mathrm{RFI}^{-}$pigs. Both lactate dehydrogenase activity participating in glucose metabolism and hydroxylacyl-CoA dehydrogenase activity involved in fatty acid oxidation were greater $(P<0.05)$ in the liver and $\mathrm{LM}$ of $\mathrm{RFI}^{+}$pigs compared with $\mathrm{RFI}^{-}$pigs. In the liver, contrary to the LM, those differences in enzyme activities were directly associated with selection on RFI regardless of ADFI. Increased backfat depth and content and greater lipid content and adipocyte hypertrophy $(P<0.05)$ in subcutaneous adipose tissue were reported in $\mathrm{RFI}^{+}$pigs compared with $\mathrm{RFI}^{-}$pigs at $115 \mathrm{~kg} \mathrm{BW}$ without marked changes in key lipogenic enzyme activities; these changes were directly associated with ADFI. In conclusion, the present study shows an increase of catabolic pathway activities in the liver and muscle of $\mathrm{RFI}^{+}$pigs at market weight that is likely to generate more ATP compared with $\mathrm{RFI}^{-}$pigs.

Key words: energy metabolism, liver, muscle, pig, protein turnover, residual feed intake

(C) 2012 American Society of Animal Science. All rights reserved.

J. Anim. Sci. 2012.90:4771-4780

doi:10.2527/jas2012-5226

INTRODUCTION

\footnotetext{
${ }^{1}$ We thank Y. Billon, R. Janvier, V. Piedvache, A. Priet, and P. Roger for animal care, F. Le Gouevec and A. Chauvin for surgery, M. Alix, J. Liger, and J.F. Rouault for animal slaughtering and carcass cutting, and P. Ecolan, P. Ganier, S. Tacher, J.N. Thibault, and C. Tréfeu for their help in tissue sampling and expert technical assistance. We are also grateful to L. Lefaucheur for critical reading of the manuscript.

${ }^{2}$ The study was funded by the French National Research Agency (Agence Nationale de la Recherche ANR, ANR-08-GENM038 PIG_FEED). T. Le Naou was supported by a scholarship from INRA and the research fund of Region Bretagne (France).

${ }^{3}$ Corresponding author: florence.gondret@rennes.inra.fr

Received February 21, 2012.

Accepted July 22, 2012.
}

Improving feed efficiency to reduce feed cost and environmental impacts is one of the main goals of pig production. Feed efficiency can be estimated by individual residual feed intake (RFI). Briefly, RFI is the difference between the observed feed consumption of an animal and that predicted on the basis of requirements for maintenance and production of a reference population. Recent selection experiments on RFI in pigs have shown that variations in feeding behavior and daily feed intake (DFI; Young et al., 2011) and changes in heat production due 
to physical activity and basal metabolic rate (Barea et al., 2010) are related to RFI. Moreover, reduced RFI is genetically correlated with a decreased body fatness (Gilbert et al., 2007) and phenotypically associated with the downregulation of several genes involved in lipid metabolism in adipose tissue (Lkhagvadorj et al., 2010). Greater muscle glycogen content at commercial weight and greater drip loss and lower ultimate $\mathrm{pH}$ in meat were reported in low RFI pigs compared with high RFI pigs (Lefaucheur et al., 2011). Together, these studies suggest that RFI variability in pigs may be related to lipid and glucose metabolisms in key tissues. Differences in protein degradation rate or protein synthesis could also give rise to changes in the efficiency of conversion of feed to BW gain in various species (Herd and Arthur, 2009). Finally, differences in some plasma metabolites and hormones have been positively related to genetic and phenotypic measures of RFI in ruminants (Richardson and Herd, 2004).

This study aimed to identify early and long-term modifications in energy or protein turnover in key tissues and their cross talks in response to a divergent selection experiment on RFI in growing pigs. Because high RFI pigs were anticipated to have a greater feed intake than low RFI pigs, subsets of pigs were also pair-fed to decipher the direct effects of RFI genetic divergence on metabolic orientation.

\section{MATERIALS AND METHODS}

The care and use of pigs were performed in compliance with the guidelines of the French Ministry of Agriculture and Fisheries for animal research.

\section{Animals}

Purebred French Large White female pigs in the course of a divergent selection experiment on RFI were produced at 2 research farms [INRA Genetique Porcine -GEPA (GEPA), Rouillé and Le Magneraud, France]. The selection program, started at INRA in 2000, was previously described (Gilbert et al., 2007). Briefly, DFI and ADG from 35 to $95 \mathrm{~kg}$ were recorded on male candidates to selection together with backfat thickness at 95 $\mathrm{kg}$ (UBT) averaged from 6 measures taken by ultrasonic scanning (ALOKA SSD-500 echograph; Aloka, Cergy Pontoise, France) at right and left shoulder, right and left midback, and right and left loin. A RFI selection index was computed as a linear combination of those traits to account for growth requirement as follows:

$$
\mathrm{RFI}=\mathrm{DFI}-(1.24 \times \mathrm{ADG})-(31.9 \times \mathrm{UBT}),
$$

in which RFI, DFI, and ADG are measured in grams and UBT is measured in millimeters.

For genetic analysis, RFI of boars was computed us- ing their own records for DFI, ADG, and UBT and taking into account the fixed effects of contemporary group and pen size. The $\mathrm{R}^{2}$ of the model used to compute the predicted feed intake of P1 animals was 0.66 (Gilbert et al., 2007). In the present study, pigs from the sixth and seventh generations of this divergent selection experiment were considered. Average genetic values of RFI were $67.16(\mathrm{SE}=2.79) \mathrm{g} / \mathrm{d}$ for the high RFI line and $-70.34(\mathrm{SE}=3.31) \mathrm{g} / \mathrm{d}$ for the low RFI line, respectively, which were not different from the average values of these generations.

At weaning ( $28 \mathrm{~d}$ of age), 36 and 26 female piglets from the high and low RFI lines, respectively, were transferred to the experimental facilities of INRA Physiologie, Environnement et Genetique pour l'Animal et les Systèmes d'Elevage (PEGASE; Saint-Gilles, France) in 2 successive replicates. Piglets from the low RFI (RFI') and high RFI $\left(\mathbf{R F I}^{+}\right)$lines were chosen so that their BW $(8.7 \pm 0.9$ and $9.0 \pm 1.1 \mathrm{~kg}$, respectively) were representative of the average weaning BW in their contemporary groups. Piglets from a first subset ( $\mathrm{n}=8$ per treatment) were individually housed in metabolic cages. They were offered free access to feed until $19 \mathrm{~kg} \mathrm{BW}$ to investigate early response to selection on tissue traits. They were weighed weekly, and individual feed consumption (offered food minus refusals) was recorded daily.

The remaining piglets $(n=46)$, which were littermates of those retained for the first subset, were housed in collective pens ( 1 pen per line) at their arrival in the postweaning facilities. They were offered free access to feed during this period. At $67 \pm 1 \mathrm{~d}$ of age (corresponding to $25 \pm 2 \mathrm{~kg} \mathrm{BW}$ in the RFI ${ }^{-}$group and $29 \pm 5 \mathrm{~kg} \mathrm{BW}$ in the $\mathrm{RFI}^{+}$group, respectively), piglets were moved to growing facilities, where they were individually housed until commercial slaughter weight $(115 \pm 3 \mathrm{~kg}$ BW $)$. Pigs had free access to transition diets the first week and were then allocated in 3 experimental treatments from the second week onwards: a first treatment composed of the $\mathrm{RFI}^{-}$pigs having free access to feed $(\mathrm{n}=18)$, a second treatment composed of $\mathrm{RFI}^{+}$pigs having free access to feed $(n=14)$, and a third treatment composed of $\mathrm{RFI}^{+}$pigs offered feed at the same level per metabolic $\mathrm{BW}\left(\mathrm{BW}^{0.60}\right)$ as $\mathrm{RFI}^{-}$pigs $\left(\mathbf{R F I}^{+\mathbf{R}} ; \mathrm{n}=14\right)$. Sisters were allocated into $\mathrm{RFI}^{+}$and $\mathrm{RFI}^{+\mathrm{R}}$ treatments so that their BW at entering in growing facilities did not differ. Pigs were weighed weekly and in the morning on the day of slaughter. Feed consumption was recorded daily. Daily feed allocated to $\mathrm{RFI}^{+\mathrm{R}}$ pigs was calculated weekly, based on the average daily feed consumption recorded during the week before in $\mathrm{RFI}^{-}$group, the average $\mathrm{BW}$ of $\mathrm{RFI}^{-}$and $\mathrm{RFI}^{+\mathrm{R}}$ pigs at the day of calculation, and the predicted ADG of $\mathrm{RFI}^{-}$pigs for the week after. Throughout the experiment, animals had free access to water and were fed standard diets formulated for postweaning and 
Table 1. Ingredients and chemical composition of diets (as-fed basis) fed to growing pigs

\begin{tabular}{lccc}
\hline \hline Item & Starter 1 & Starter 2 & Growing \\
\hline Ingredient, \% & & 23.2 & 26.2 \\
Wheat & & 25.0 & 16.0 \\
Corn & 45.3 & 24.1 & 25.5 \\
Barley & & & 5.0 \\
Wheat bran & 17.5 & 22.6 & 19.0 \\
Soybean meal & 2.5 & & \\
Soy protein concentrate & 2.3 & 0.5 & 2.0 \\
Vegetable (corn) oil & & & 3.0 \\
Molasses & 20.0 & & \\
Whey & 8.0 & & \\
Lactose & 1.41 & 1.13 & 1.29 \\
Calcium carbonate & 0.80 & 0.97 & \\
Monocalcium phosphate & & & 0.50 \\
Dicalcium phosphate & & 0.40 & 0.45 \\
Salt & 0.50 & 0.50 & 0.50 \\
Vitamin-mineral premix & 19.0 & 18.0 & 16.5 \\
Chemical composition and nutritional values, \% & & 4.2 \\
CP & 6.7 & 2.8 & 8.4 \\
Crude fats & 12.8 & 11.4 & 9.67 \\
Digestible Lysine, \% & 10.63 & 9.67 & \\
NE, kJ/g & & & \\
\hline
\end{tabular}

growing periods (Table 1). The ADG, DFI, total feed intake, and G:F were then computed for the postweaning and growing periods.

\section{Animal Slaughtering and Sample Collection}

Pigs for studying short- or long-term responses to RFI selection were slaughtered at $19 \pm 1$ and $115 \pm 3 \mathrm{~kg} \mathrm{BW}$, respectively. Pigs were killed $2 \mathrm{~h}$ after their last morning meal, by jugular exsanguination after electronarcosis. At bleeding, a blood sample $(10 \mathrm{~mL})$ was collected on EDTA $(1.95 \mathrm{mg} / \mathrm{mL})$ and centrifuged for $15 \mathrm{~min}$ at $2,500 \times \mathrm{g}$ at $4{ }^{\circ} \mathrm{C}$. Plasma was stored at $-20^{\circ} \mathrm{C}$ until analysis.

Dorsal subcutaneous adipose tissue (SCAT), comprising all fat layers, was sampled immediately after death by an incision along the dorsal right side of the body at the last rib. The carcass was then prepared by removing digestive, urogenital, and respiratory tracts. Liver and kidneys were weighed, and the liver was sampled. Perirenal fat was removed and weighed. A sample of the LM was collected within 20 min of death at the last rib on the right carcass side, just below the adipose tissue sampling location. All tissue samples were cut into small pieces, snap frozen in $\mathrm{N}_{2}$, and stored at $-75^{\circ} \mathrm{C}$ until biochemical analyses. Another SCAT sample was restrained onto flat sticks and frozen in $\mathrm{N}_{2}$ for histological measurements. For pigs killed at $115 \mathrm{~kg}$, backfat and muscle thicknesses (means of measurements between the third and fourth lumbar vertebra and the third and fourth last rib) were obtained by ultrasonic measure- ments on the hot carcass using a Fat Lean Meter (CGM, Sydel, Lorient, France). These parameters were also used to estimate the lean meat content (Daumas, 2008). The carcass was then chilled at $4^{\circ} \mathrm{C}$. The next day, the left-half carcass side was weighed and dissected into its main cuts (backfat, belly, loin, ham, and shoulder). The LM was dissected from the loin and individually weighed. Weights of all cuts were then expressed as percentage of the left chilled-carcass weight.

\section{Tissue Lipid Content}

Concentration of total lipids was determined in SCAT, LM, and the liver samples using a chloroform and methanol (2:1) extraction procedure (Folch et al., 1957). Total amounts of lipids in those tissues were calculated by considering the weight of tissues before sampling.

\section{Adipose Tissue Cellularity}

Histological methods were used to determine adipocyte mean diameter. Frozen SCAT was sectioned at $12-\mu \mathrm{m}$ thickness on a cryostat (2800 Frigocut; ReichertJung, Francheville, France) at $-30^{\circ} \mathrm{C}$, mounted on slides, and stained with Oil Red $\mathrm{O}$ solution to reveal lipids within cells (Gardan et al., 2006). Cross sections were counterstained with a crystal violet solution $(0.05 \%)$ to reveal adipocyte membranes. Images of adipocytes were obtained at a 10 -fold magnification with a digital camera system (CV-M90; Jai, Glostrup, Denmark). Five slides were prepared per SCAT sample, and images with the best membrane integrity were retained for cellular analyses (at least 200 adipocytes per sample). Cross-sectional area of each adipocyte in the image was measured using a digitizing table and image analysis software (Visilog 6.0 Imaging software; Noesis, Courtaboeuf, France). The mean diameter $(\mu \mathrm{m})$ was then calculated considering adipocytes as spherical cells. The number of adipocytes per gram of tissue was estimated by dividing lipid content per gram of tissue by the estimated mean volume of adipocytes in the sample.

\section{Enzyme Activities}

Activities of several enzymes involved in lipid synthesis, energy catabolism, or protein degradation were monitored in tissues. To calculate specific enzyme activities, protein content in the assayed supernatants was measured using Bradford reagent with BSA as standard (Bradford, 1976).

Activities of enzymes participating in de novo lipogenesis were assessed in SCAT and the liver. Tissue samples (500 mg for SCAT and $200 \mathrm{mg}$ for the liver) 
were homogenized in $0.25 \mathrm{~mol} / \mathrm{L}$ ice-cold sucrose solution containing EDTA $(1 \mathrm{mmol} / \mathrm{L})$ and dithiothreitol (DTT; $1 \mathrm{mmol} / \mathrm{L}$ ). Mixtures were ultracentrifuged at $100,000 \times g$ for $1 \mathrm{~h}$ at $4^{\circ} \mathrm{C}$. The resulting supernatants containing cytosolic proteins were collected and frozen at $-75^{\circ} \mathrm{C}$ until use. Specific activities of malic enzyme, glucose-6-phosphate dehydrogenase (G6PDH), and fatty acid synthase (FAS) were assayed spectrophotometrically at 340-nm absorbance, as described previously (Bazin and Ferre, 2001).

Activities of lactate dehydrogenase (LDH) involved in glucose metabolism, $\beta$-hydroxylacyl-CoA dehydrogenase (HAD) involved in fatty acid $\beta$-oxidation, and citrate synthase (CS) participating to terminal oxidation of nutrients within the Krebs cycle were also assayed in the LM and the liver. Samples (approximately $300 \mathrm{mg}$ ) were homogenized in a $0.1 \mathrm{~mol} / \mathrm{L}$ phosphate buffer $(\mathrm{pH}=7.5)$ containing EDTA ( $2 \mathrm{mmol} / \mathrm{L})$. Mixtures were sonicated $(60 \mathrm{~s}$ at $50 \mathrm{~Hz})$ and centrifuged $(1,500 \times \mathrm{g}$ for $13 \mathrm{~min}$ at $\left.4^{\circ} \mathrm{C}\right)$. Supernatants were stored in ice. Specific activities were assayed spectrophotometrically at $340-\mathrm{nm}$ absorbance for LDH (Vassault, 1983) and HAD (Bass et al., 1969) and at 405-nm absorbance for CS (Srere, 1969).

Activities of the proteasome, the key enzyme of the ubiquitin-dependent proteolysis, and of calpains ( $\mu$-calpain and m-calpain) involved in $\mathrm{Ca}^{2+}$-dependent proteolysis were assayed in the LM and the liver. Samples $(50 \mathrm{mg})$ were homogenized in a $20 \mathrm{mmol} / \mathrm{L}$ Tris-HCl buffer $(\mathrm{pH}=7.2)$ containing DTT $(1 \mathrm{mmol} / \mathrm{L})$ and Triton X100 (1\%; Sigma, Steinheim, Germany). Mixtures were then centrifuged for $15 \mathrm{~min}$ at 12,000 $\times g$ at $4^{\circ} \mathrm{C}$. Activities were assayed by fluorometry at $355 \mathrm{~nm}$ for excitation and $460 \mathrm{~nm}$ for emission (Jamin et al., 2012), using clasto-lactacystin- $\beta$-lactone as proteasome inhibitor (VWR, Fontenay sous Bois, France) and MDL-28170 as calpain inhibitor (Tebu-Bio, Le Perray en Yvelines, France).

\section{Plasma Metabolite and Hormone Concentrations}

Commercial kits were used to determine plasma concentrations of glucose (Glucose RTU; bioMérieux, Craponne, France), lactate (Lactate PAP; bioMérieux), NEFA (NEFA-HR(2); Wako Chemicals GmbH, Neuss, Germany), urea (Urea UV 250; bioMérieux), proteins (Protéines-kit; bioMérieux), triglycerides (Triglycérides Enzymatique PAP 150; bioMérieux), $\beta$-hydroxybutyrate (Thermo Fisher, Illkirch, France), and albumin (Albuminkit; bioMérieux). These parameters were measured with a Konelab 20i device (Thermo Fisher Scientific, Courtaboeuf, France). Intra-assay CV were less than 5\%.

Plasma concentrations of insulin were measured using a RIA kit (INSULIN-CT; CisBio Bioassays, Codolet, France). Plasma leptin concentrations were quantified us- ing the multispecies RIA kit (Millipore, St. Charles, MO) previously validated for use in porcine plasma (Qian et al., 1999). Intra-assay CV for these hormones were $<6 \%$. Plasma concentrations of total triiodothyronine (TT3) and total thyroxin (TT4) were determined using commercial RIA kits (MP Biomedicals, Illkirch Graffenstaden, France). Plasma IGF-I concentrations were determined using a double antibody RIA (Louveau and Bonneau, 1996) after an acid-ethanol extraction (Daughaday et al., 1980). The intra-assay CV for plasma sample with a mean IGF-I concentration of $302 \mathrm{ng} / \mathrm{mL}$ was $7.3 \%$.

\section{Protein Synthesis}

The day before slaughter at $19 \mathrm{~kg} \mathrm{BW}$, piglets were fitted with a catheter in the jugular vein as described by Matte (1999). On the day of slaughter, blood samples $(3 \mathrm{~mL})$ were collected on heparin $(50 \mathrm{UI} / \mathrm{mL})$ from the catheter just before, $7 \mathrm{~min}$ after, and $14 \mathrm{~min}$ after an injection of a flooding dose of valine $(1.50 \mathrm{mmol} / \mathrm{kg} \mathrm{BW}$ of a solution composed of $20 \% \mathrm{~L}^{-15}[\mathrm{~N}]-\mathrm{Val}$ and $80 \% \mathrm{~L}-$ Val) to measure protein synthesis (Hamard et al., 2009). Piglets were killed 15 min after valine injection. Tissue protein synthesis rate was then determined in sampled liver and LM. Plasma-free valine enrichment $\left(\mathbf{S}_{\mathbf{A}}\right)$ was determined by GC-MS [gas chromatography (GC) 7890A coupled with a mass spectrometer (MS) 5975C; Agilent Technology, Santa Clara, CA] after derivatization with N-tert-butyldimethylsilyl N-methyl-trifluoroacetamide. Protein-bound valine enrichment $\left(\mathbf{S}_{\mathbf{B}}\right)$ was measured by GC-C-IRMS [gas chromatography 8131 coupled to an isotopic Isochrom mass spectrometry (IRMS); Fisons Instrument (GV Instruments, Manchester, UK)] after derivatization with ethylchloroformate. Fractional protein synthesis rate $\left(\mathbf{K}_{\mathrm{S}} ; \% / \mathrm{d}\right)$, corresponding to the percentage of protein newly synthesized per day, was calculated as follows:

$$
\mathrm{K}_{\mathrm{S}}=\left(\mathrm{S}_{\mathrm{B}} \times 100\right) /\left(\mathrm{S}_{\mathrm{A}} \times \mathrm{t}\right),
$$

in which $S_{B}$ represents plasma enrichment, $S_{A}$ represents the tissue protein enrichment, and t represents the time elapsed between the injection of valine and animal bleeding.

\section{Statistical Analysis}

Data were processed using SAS Software (SAS Inst. Inc., Cary, NC) and analyzed within each slaughtering weight (19 or $115 \mathrm{~kg} \mathrm{BW}$ ). Data were processed by ANOVA using the GLM procedure considering the fixed effects of the experimental treatments, replicates, and the interaction between treatment and replicate (treatment $\times$ replicate). For performance traits during the grow- 
ing period, BW at $67 \mathrm{~d}$ of age was also included as an additional covariate in complementary analyses. The final BW was added as covariate for carcass traits, tissue lipid composition, and cellular and biochemical data determined at slaughter. Litter within experimental group was first considered as a random effect but was removed from the models as it was generally not significant. When a statistical difference was found for the effect of experimental treatments, least square means were compared. Differences were considered significant for $P \leq 0.05$ whereas $0.05<P \leq 0.10$ was discussed as a trend.

\section{RESULTS}

\section{Growth Performance, Carcass Composition, and Tissue Composition}

From $28 \mathrm{~d}$ of age to $19 \pm 1 \mathrm{~kg} \mathrm{BW}$ at slaughter (53.2 $\pm 0.8 \mathrm{~d}$ of age on average), ADG did not differ $(P>0.10)$ between $\mathrm{RFI}^{-}$and $\mathrm{RFI}^{+}$treatments $(370 \mathrm{~g} / \mathrm{d}$ on average). Daily feed consumption was less $(P=$ $0.03)$ in $\mathrm{RFI}^{-}$piglets $(551 \pm 59 \mathrm{~g} / \mathrm{d})$ than in $\mathrm{RFI}^{+}$piglets $(625 \pm 59 \mathrm{~g} / \mathrm{d})$. Moreover, $\mathrm{G}: \mathrm{F}$ tended $(P=0.09)$ to be greater in $\mathrm{RFI}^{-}$than $\mathrm{RFI}^{+}$pigs $(0.74$ vs. 0.70 for $\mathrm{RFI}^{-}$and $\mathrm{RFI}^{+}$treatments, respectively). At postweaning period, carcass weight $(13.6 \pm 0.3 \mathrm{~kg})$, the liver and kidneys weights, and the perirenal fat proportion (relative to BW) did not differ $(P>0.10)$ between the 2 treatments (data not shown).

From $67 \pm 1 \mathrm{~d}$ of age to $115 \pm 2 \mathrm{~kg} \mathrm{BW}$ at slaughter (growing period), ADG was lesser in $\mathrm{RFI}^{-}$pigs compared with $\mathrm{RFI}^{+}$pigs $(-37 \mathrm{~g} / \mathrm{d} ; P<0.001$; Table 2$)$; however, ADG did not differ $(P>0.10)$ between those 2 treatments when adjusted for respective BW at $67 \mathrm{~d}$ of age. Both DFI and total feed consumption during this period were lesser in $\mathrm{RFI}^{-}$pigs than $\mathrm{RFI}^{+}$pigs (-8 and $-13 \%$, respectively). Consequently, G:F was improved $(P<0.001)$ in $\mathrm{RFI}^{-}$pigs compared with $\mathrm{RFI}^{+}$pigs. As expected according to experimental design, feed metabolic consumption was similar $(P>0.10)$ in $\mathrm{RFI}^{-}$and $\mathrm{RFI}^{+\mathrm{R}}$ pigs $\left(182 \mathrm{~g} \cdot \mathrm{d}^{-1} \cdot \mathrm{kg}^{-1} \mathrm{BW}\right.$ on average). Feed restriction in $\mathrm{RFI}^{+\mathrm{R}}$ pigs lowered ADG $(P<0.001)$ when compared with their $\mathrm{RFI}^{+}$littermates but did not modify $\mathrm{G}: \mathrm{F}(P>0.10 ; 0.35 \mathrm{~kg}$ gain $/ \mathrm{kg}$ feed in both treatments). At slaughter, carcass weight did not differ $(P>0.05)$ among the 3 treatments (Table 2). The RFI ${ }^{-}$pigs had the lowest backfat depth and content and a lower proportion of belly when compared with $\mathrm{RFI}^{+}$pigs $(P<0.05)$. Conversely, they displayed a greater lean meat content and increased proportions of loin and shoulder compared with $\mathrm{RFI}^{+}$pigs $(P<0.05)$. However, LM weight did not differ $(P>0.10)$ between $\mathrm{RFI}^{-}$and $\mathrm{RFI}^{+}$pigs. Carcass composition of $\mathrm{RFI}^{+\mathrm{R}}$ pigs was similar $(P>0.10)$ to that of $\mathrm{RFI}^{-}$pigs, except for shoulder proportion that was
Table 2. Growth performance and carcass traits in pigs divergently selected on low residual feed intake $\left(\mathrm{RFI}^{-}\right)$ or on high residual feed intake $\left(\mathrm{RFI}^{+}\right)$having either free access to feed or offered feed at the same level per metabolic BW (BW0.60) as RFI- pigs $\left(\mathrm{RFI}^{+\mathrm{R}}\right)$ access to feed from $67 \mathrm{~d}$ of age to slaughter ${ }^{1}$

\begin{tabular}{|c|c|c|c|c|c|}
\hline Item & $\mathrm{RFI}^{-}$ & $\mathrm{RFI}^{+}$ & $\mathrm{RFI}^{+\mathrm{R}}$ & RSD & $P$-value \\
\hline $\mathrm{N}$ & 18 & 14 & 14 & & \\
\hline \multicolumn{6}{|l|}{ Growth traits } \\
\hline 67-d-old BW, kg & $25.2^{\mathrm{a}}$ & $29.2^{\mathrm{b}}$ & $29.3^{\mathrm{b}}$ & 3.8 & $<0.01$ \\
\hline Final BW, kg & 114.9 & 114.8 & 114.7 & 3.2 & 0.99 \\
\hline Final age, d & $170^{\mathrm{b}}$ & $162^{\mathrm{a}}$ & $173^{b}$ & 8 & $<0.01$ \\
\hline $\mathrm{ADG}, \mathrm{g} / \mathrm{d}$ & $877^{\mathrm{b}}$ & $914^{\mathrm{c}}$ & $813^{\mathrm{a}}$ & 52 & $<0.001$ \\
\hline \multicolumn{6}{|l|}{ Feed intake } \\
\hline Total feed intake, $\mathrm{kg}$ & $228^{\mathrm{a}}$ & $248^{\mathrm{b}}$ & $245^{\mathrm{b}}$ & 16 & $<0.01$ \\
\hline 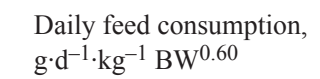 & $182^{\mathrm{a}}$ & $209^{b}$ & $183^{\mathrm{a}}$ & 14 & $<0.001$ \\
\hline $\mathrm{G}: \mathrm{F}$ & $0.39^{\mathrm{b}}$ & $0.35^{\mathrm{a}}$ & $0.35^{\mathrm{a}}$ & 0.02 & $<0.001$ \\
\hline \multicolumn{6}{|l|}{ Organ weight, g } \\
\hline Liver & $2,049^{\mathrm{a}}$ & $2,251^{\mathrm{b}}$ & $2,009^{\mathrm{a}}$ & 179 & $<0.01$ \\
\hline Kidneys & $394^{\mathrm{a}}$ & $445^{\mathrm{b}}$ & $393^{\mathrm{a}}$ & 51 & 0.03 \\
\hline Perirenal fat & $1,113^{\mathrm{a}}$ & $1,248^{\mathrm{b}}$ & $1,043^{\mathrm{a}}$ & 211 & 0.08 \\
\hline \multicolumn{6}{|l|}{ Carcass traits } \\
\hline $\begin{array}{l}\text { Chilled carcass } \\
\text { weight, } \mathrm{kg}\end{array}$ & 88.1 & 88.4 & 87.8 & 1.7 & 0.63 \\
\hline $\begin{array}{l}\text { Mean backfat } \\
\text { thickness, mm }\end{array}$ & $16.8^{\mathrm{a}}$ & $19.0^{\mathrm{b}}$ & $16.7^{\mathrm{a}}$ & 2.5 & 0.03 \\
\hline Lean meat content, $\%$ & $59.3^{\mathrm{b}}$ & $57.6^{\mathrm{a}}$ & $58.9^{\mathrm{b}}$ & 1.7 & 0.02 \\
\hline \multicolumn{6}{|l|}{ Carcass composition, $\%^{2}$} \\
\hline Backfat & $6.7^{\mathrm{a}}$ & $7.7^{\mathrm{b}}$ & $7.0^{\mathrm{a}}$ & 1.0 & 0.04 \\
\hline Belly & $13.7^{\mathrm{a}}$ & $15.0^{\mathrm{b}}$ & $13.6^{\mathrm{a}}$ & 1.2 & $<0.01$ \\
\hline Shoulder & $24.8^{\mathrm{b}}$ & $24.1^{\mathrm{a}}$ & $24.2^{\mathrm{a}}$ & 0.5 & $<0.01$ \\
\hline Ham & 23.9 & 23.9 & 24.0 & 0.8 & 0.92 \\
\hline Loin & $27.8^{\mathrm{b}}$ & $26.4^{\mathrm{a}}$ & $28.3^{\mathrm{b}}$ & 1.5 & $<0.01$ \\
\hline LM & 3.5 & 3.0 & 3.1 & 0.7 & 0.17 \\
\hline
\end{tabular}

greater $(P<0.01)$ in $\mathrm{RFI}^{-}$pigs than in $\mathrm{RFI}^{+\mathrm{R}}$ pigs.

\section{Lipid-Related Traits}

At $19 \pm 1 \mathrm{~kg} \mathrm{BW}$, lipid contents of SCAT (60.2 $\mathrm{g} \pm$ $5.5 \mathrm{~g}$ per $100 \mathrm{~g}$ of fresh tissue weight on average), LM $(1.5 \mathrm{~g} \pm 0.2 \mathrm{~g} / 100 \mathrm{~g}$ on average $)$, and the liver $(3.9 \mathrm{~g} \pm 0.2$ $\mathrm{g} / 100 \mathrm{~g}$ on average $)$ did not differ $(P>0.05)$ between the 2 RFI treatments (data not shown). A 3-fold greater $(P=$ 0.05 ) activity of malic enzyme was found in the liver of $\mathrm{RFI}^{-}$pigs compared with $\mathrm{RFI}^{+}$pigs whereas the specific activities of FAS and G6PDH did not differ $(P>0.05)$ between the 2 treatments in that organ (Table 3). In SCAT, there were no differences $(P>0.05)$ in the activity levels of the 3 lipogenic enzymes under investigation.

At $115 \mathrm{~kg} \pm 2 \mathrm{~kg} \mathrm{BW}$, decreased concentration 
$(-5 \% ; P<0.05)$ and total amount $(-19 \% ; P<0.01)$ of lipids were reported in SCAT from $\mathrm{RFI}^{-}$pigs compared with $\mathrm{RFI}^{+}$pigs (Table 4) whereas the same traits were rather similar in $\mathrm{RFI}^{-}$and $\mathrm{RFI}^{+\mathrm{R}}$ pigs. Mean diameter of adipocytes was smaller $(-7 \%)$ in $\mathrm{RFI}^{-}$pigs than $\mathrm{RFI}^{+}$ pigs, and it was the least in $\mathrm{RFI}^{+\mathrm{R}}$ pigs $(P=0.04)$. The number of adipocytes was conversely greater in SCAT of $\mathrm{RFI}^{+\mathrm{R}}$ pigs when compared with $\mathrm{RFI}^{+}$pigs and $\mathrm{RFI}^{-}$ pigs $(P=0.08)$. The specific activities of key lipogenic enzymes in SCAT did not differ $(P>0.10)$ among the 3 treatments. In the liver and LM, the lipid concentration did not differ $(P>0.05)$ among the 3 treatments; however, the total amount of lipids in the liver was slightly lower $(P=0.07)$ in $\mathrm{RFI}^{-}$pigs than $\mathrm{RFI}^{+}$pigs (Table 4). Hepatic lipogenic enzyme activities did not differ $(P>0.10)$ among the 3 treatments.

Table 3. Specific activities of key enzymes involved in lipid synthesis, energy catabolism or protein degradation, and rate of protein synthesis in tissues of piglets divergently selected on low residual feed intake $\left(\mathrm{RFI}^{-}\right)$or high residual feed intake $\left(\mathrm{RFI}^{+}\right)$and killed at $19 \mathrm{~kg} \mathrm{BW}^{1}$

\begin{tabular}{|c|c|c|c|c|c|}
\hline Item & & $\mathrm{RFI}^{-}$ & $\mathrm{RFI}^{+}$ & RSD & $P$-value \\
\hline $\mathrm{N}$ & & 8 & 8 & & \\
\hline \multicolumn{6}{|c|}{ Lipogenic enzyme activities $^{2}$} \\
\hline $\mathrm{SCAT}^{3}$ & FAS & 13.7 & 13.7 & 3.9 & 0.97 \\
\hline SCAT & Malic enzyme & 156 & 239 & 108 & 0.15 \\
\hline SCAT & G6PDH & 167 & 193 & 46 & 0.29 \\
\hline Liver & FAS & 19.9 & 18.7 & 3.5 & 0.54 \\
\hline Liver & Malic enzyme & 34.3 & 11.1 & 20.1 & 0.05 \\
\hline Liver & G6PDH & 41.8 & 35.8 & 11.3 & 0.31 \\
\hline \multicolumn{6}{|c|}{ Enzyme activities of energy catabolism ${ }^{4}$} \\
\hline Liver & LDH & 1.26 & 1.07 & 0.53 & 0.48 \\
\hline Liver & HAD & 0.022 & 0.025 & 0.012 & 0.61 \\
\hline Liver & $\mathrm{CS}$ & 0.23 & 0.23 & 0.10 & 0.92 \\
\hline $\mathrm{LM}$ & LDH & 14.9 & 14.2 & 3.6 & 0.73 \\
\hline LM & HAD & 0.049 & 0.052 & 0.015 & 0.66 \\
\hline LM & $\mathrm{CS}$ & 0.104 & 0.098 & 0.028 & 0.71 \\
\hline \multicolumn{6}{|c|}{ Enzyme activities of protein catabolism ${ }^{5}$} \\
\hline Liver & Proteasome & 109 & 91 & 18 & 0.08 \\
\hline Liver & Calpains & 211 & 206 & 31 & 0.76 \\
\hline LM & Proteasome & 14.1 & 15.2 & 5.0 & 0.66 \\
\hline LM & Calpains & 4.0 & 5.3 & 4.5 & 0.60 \\
\hline \multicolumn{6}{|c|}{ Protein synthesis $^{6}$} \\
\hline Liver & $\mathrm{K}_{\mathrm{S}}$ & 102 & 89 & 11 & 0.06 \\
\hline LM & $\mathrm{K}_{\mathrm{S}}$ & 10.0 & 9.2 & 1.5 & 0.35 \\
\hline
\end{tabular}

${ }^{1}$ Values are least square means. RSD $=$ residual SD (corresponding to the root-mean-square error of the full ANOVA model).

${ }^{2}$ Activities of fatty acid synthase (FAS), malic enzyme, or glucose-6-phosphate dehydrogenase (G6PDH) are expressed as nmol $\cdot \mathrm{min}^{-1} \cdot \mathrm{mg}^{-1}$ protein.

${ }^{3} \mathrm{SCAT}=$ subcutaneous adipose tissue.

${ }^{4}$ Activities of lactate dehydrogenase (LDH), $\beta$-hydroxylacyl-CoA dehydrogenase (HAD), or citrate synthase (CS) are expressed as $\mu \mathrm{mol} \cdot \mathrm{min}^{-1} \cdot \mathrm{mg}^{-1}$ protein.

${ }^{5}$ Activities are expressed as milliRFU $\cdot \mathrm{min}^{-1} \cdot \mathrm{mg}^{-1}$ protein. $\mathrm{RFU}=$ relative fluorescent unit.

${ }^{6}$ Fractional rate $\left(\mathrm{K}_{\mathrm{S}}\right)$ is expressed as percent per day.

\section{Energy Catabolism and Protein Turnover}

At $19 \mathrm{~kg} \pm 1 \mathrm{~kg} \mathrm{BW}$, activity levels for $\mathrm{LDH}$, $\mathrm{HAD}$, and CS in LM as well as in the liver did not differ $(P>0.10)$ between $\mathrm{RFI}^{-}$and $\mathrm{RFI}^{+}$piglets (Table 3 ). Proteasome activity and the $\mathrm{K}_{\mathrm{S}}$ in the liver tended to be greater $(P<0.10)$ in $\mathrm{RFI}^{-}$piglets than in $\mathrm{RFI}^{+}$piglets. The activities of key proteolytic enzymes and the rate of protein synthesis in the LM did not differ $(P>0.05)$ between the 2 treatments.

At $115 \pm 2 \mathrm{~kg} \mathrm{BW}$, the specific activity of LDH was lower in the LM $(-13 \% ; P<0.05)$ and the liver $(-7 \%$; $P<0.05$ ) of $\mathrm{RFI}^{-}$pigs than $\mathrm{RFI}^{+}$pigs (Table 5). Similarly, HAD activity was reduced in LM $(P<0.001)$ and the liver $(P<0.05)$ of $\mathrm{RFI}^{-}$pigs compared with $\mathrm{RFI}^{+}$pigs. The specific activity of CS in LM was also less $(P<0.01)$ in $\mathrm{RFI}^{-}$pigs than in $\mathrm{RFI}^{+}$pigs but did not differ $(P>0.05)$ between those treatments in the liver. Feed restriction in $\mathrm{RFI}^{+\mathrm{R}}$ pigs did not change $(P>0.05)$ the activity of $\mathrm{LDH}$, $\mathrm{HAD}$, and CS in the liver, but it decreased the specific activities of those enzymes in LM to a level similar to $\mathrm{RFI}^{-}$ pigs (for LDH) or intermediate between $\mathrm{RFI}^{-}$and $\mathrm{RFI}^{+}$

Table 4. Lipid-related characteristics of pigs divergently selected on low residual feed intake $\left(\mathrm{RFI}^{-}\right)$or high residual feed intake $\left(\mathrm{RFI}^{+}\right)$and having either free access to feed or offered feed at the same level per metabolic BW (BW0.60) as RFI- pigs $\left(\mathrm{RFI}^{+\mathrm{R}}\right)$ access to feed from 67 d of age to slaughter ${ }^{1}$

\begin{tabular}{|c|c|c|c|c|c|c|}
\hline \multicolumn{2}{|l|}{ Item } & $\mathrm{RFI}^{-}$ & $\mathrm{RFI}^{+}$ & $\mathrm{RFI}^{+\mathrm{R}}$ & RSD & $P$-value \\
\hline \multicolumn{2}{|l|}{$\mathrm{N}$} & 18 & 14 & 14 & & \\
\hline \multicolumn{7}{|c|}{ Lipid content, $g / 100 \mathrm{~g}$ fresh weight } \\
\hline \multicolumn{2}{|l|}{$\mathrm{SCAT}^{2}$} & $79.0^{\mathrm{a}}$ & $83.4^{\mathrm{b}}$ & $80.2^{\mathrm{ab}}$ & 4.1 & 0.03 \\
\hline \multicolumn{2}{|l|}{ LM } & 1.8 & 2.1 & 1.8 & 0.4 & 0.13 \\
\hline \multicolumn{2}{|l|}{ Liver } & 4.2 & 4.3 & 4.5 & 0.5 & 0.15 \\
\hline \multicolumn{7}{|c|}{ Total tissue lipid amount, $\mathrm{g}$} \\
\hline \multicolumn{2}{|c|}{ SCAT } & $2263^{\mathrm{a}}$ & $2791^{\mathrm{b}}$ & $2325^{\mathrm{a}}$ & 413 & $<0.01$ \\
\hline \multicolumn{2}{|l|}{ LM } & 202 & 232 & 216 & 46 & 0.26 \\
\hline \multicolumn{2}{|l|}{ Liver } & 87 & 97 & 91 & 11 & 0.07 \\
\hline \multicolumn{7}{|c|}{ Adipocyte cellularity } \\
\hline SCAT & Mean diameter, $\mu \mathrm{m}$ & $88.1^{\mathrm{ab}}$ & $94.8^{\mathrm{b}}$ & $80.3^{\mathrm{a}}$ & 1.37 & 0.04 \\
\hline \multicolumn{6}{|c|}{ billion per gram of tissue } & 0.08 \\
\hline \multicolumn{7}{|c|}{ Lipogenic enzyme activity ${ }^{3}$} \\
\hline SCAT & FAS & 17.8 & 15.1 & 20.1 & 8.3 & 0.29 \\
\hline SCAT & Malic enzyme & 309 & 386 & 376 & 123 & 0.17 \\
\hline SCAT & G6PDH & 323 & 342 & 283 & 96 & 0.26 \\
\hline Liver & FAS & 8.7 & 8.4 & 8.5 & 1.7 & 0.89 \\
\hline Liver & Malic enzyme & 4.7 & 5.6 & 5.8 & 3.0 & 0.57 \\
\hline Liver & G6PDH & 48.4 & 45.4 & 48.3 & 10.8 & 0.70 \\
\hline
\end{tabular}

${ }^{\mathrm{a}, \mathrm{b}}$ Within a row, means without a common superscript differ $(P<0.10)$.

${ }^{1}$ Values are least square means. RSD $=$ residual SD (corresponding to the root-mean-square error of the full ANOVA model).

${ }^{2} \mathrm{SCAT}=$ subcutaneous adipose tissue.

${ }^{3}$ Activities of fatty acid synthase (FAS), malic enzyme, or glucose-6-phosphate dehydrogenase $(\mathrm{G} 6 \mathrm{PDH})$ are expressed as $\mathrm{nmol} \cdot \mathrm{min}^{-1} \cdot \mathrm{mg}^{-1}$ protein. 
Table 5. Activities of key energy and protein catabolic enzymes in tissues of pigs divergently selected on low RFI $\left(\mathrm{RFI}^{-}\right)$or high residual feed intake $\left(\mathrm{RFI}^{+}\right)$and having either free access to feed or offered feed at the same level per metabolic BW (BW0.60) as RFI- pigs $\left(\mathrm{RFI}^{+\mathrm{R}}\right)$ access to feed from $67 \mathrm{~d}$ of age to slaughter ${ }^{1}$

\begin{tabular}{|c|c|c|c|c|c|c|}
\hline Item & & $\mathrm{RFI}^{-}$ & $\mathrm{RFI}^{+}$ & $\mathrm{RFI}^{+\mathrm{R}}$ & RSD & $P$-value \\
\hline $\mathrm{N}$ & & 18 & 14 & 14 & & \\
\hline \multicolumn{7}{|c|}{ Enzyme activities of energy catabolism ${ }^{2}$} \\
\hline Liver & LDH & $0.38^{\mathrm{a}}$ & $0.41^{\mathrm{ab}}$ & $0.45^{\mathrm{b}}$ & 0.07 & 0.02 \\
\hline Liver & HAD & $0.010^{\mathrm{a}}$ & $0.012^{\mathrm{b}}$ & $0.013^{\mathrm{b}}$ & 0.002 & 0.01 \\
\hline Liver & $\mathrm{CS}$ & 0.084 & 0.088 & 0.096 & 0.015 & 0.11 \\
\hline LM & LDH & $20.8^{\mathrm{a}}$ & $23.9^{\mathrm{b}}$ & $21.0^{\mathrm{a}}$ & 3.2 & 0.02 \\
\hline LM & HAD & $0.027^{\mathrm{a}}$ & $0.035^{\mathrm{b}}$ & $0.031^{\mathrm{c}}$ & 0.005 & $<0.001$ \\
\hline LM & $\mathrm{CS}$ & $0.037^{\mathrm{a}}$ & $0.046^{\mathrm{b}}$ & $0.042^{\mathrm{c}}$ & 0.006 & $<0.01$ \\
\hline \multicolumn{7}{|c|}{ Enzyme activities of protein catabolism ${ }^{3}$} \\
\hline Liver & Proteasome & 50.9 & 51.9 & 51.7 & 8.4 & 0.96 \\
\hline Liver & Calpains & 47.7 & 54.8 & 56.8 & 13.0 & 0.13 \\
\hline LM & Proteasome & 4.3 & 4.8 & 4.9 & 1.7 & 0.61 \\
\hline LM & Calpains & 20.0 & 18.7 & 22.2 & 7.8 & 0.53 \\
\hline $\begin{array}{l}{ }^{1} \text { Values are least square means. RSD }=\text { residual SD (corresponding to the } \\
\text { root-mean-square error of the full ANOVA model). }\end{array}$ & \multicolumn{6}{|c|}{${ }^{\mathrm{a}, \mathrm{b}}$ Within a row, means without a common superscript differ $(P<0.10)$} \\
\hline \multicolumn{7}{|c|}{$\begin{array}{l}{ }^{2} \text { Activities of lactate dehydrogenase (LDH), } \beta \text {-hydroxylacyl-CoA dehydroge- } \\
\text { nase (HAD), or citrate synthase (CS) are expressed as } \mu \mathrm{mol} \cdot \mathrm{min}^{-1} \cdot \mathrm{mg}^{-1} \text { proteins } \\
{ }^{3} \text { Activities are exnressed as milliRFU } \cdot \mathrm{min}^{-1} \cdot \mathrm{mg}^{-1} \text { nroteins }\end{array}$} \\
\hline
\end{tabular}

pigs (for HAD and CS). Proteasome and calpain activities did not differ $(P>0.10)$ among the 3 treatments either in $\mathrm{LM}$ or in the liver.

\section{Nutrient and Hormone Plasma Concentrations}

At $19 \pm 1 \mathrm{~kg} \mathrm{BW}$, insulin concentration was lower $(P=0.05)$ in $\mathrm{RFI}^{-}$piglets than in $\mathrm{RFI}^{+}$piglets $(36.0$ and $51.8 \mu \mathrm{UI} / \mathrm{mL}$, respectively). However, there were no differences $(P>0.10)$ in plasma concentration of nutrients and hormones between $\mathrm{RFI}^{+}$and $\mathrm{RFI}^{-}$groups (data not shown).

At $115 \pm 2 \mathrm{~kg} \mathrm{BW}$, there was notably a reduced $(P=0.04)$ plasma triglyceride concentration in $\mathrm{RFI}^{-}$pigs than in $\mathrm{RFI}^{+}$pigs (Table 6), with $\mathrm{RFI}^{+\mathrm{R}}$ pigs having triglyceride concentration intermediate between the 2 other treatments. Conversely, TT4 plasma concentration tended to be greater $(P=0.10)$ in $\mathrm{RFI}^{-}$pigs than in $\mathrm{RFI}^{+}$pigs and intermediate in $\mathrm{RFI}^{+\mathrm{R}}$ pigs. Plasma concentrations of other nutrients and hormones did not differ $(P>0.10)$ among the 3 treatments.

\section{DISCUSSION}

\section{Growth Performance Divergences Associated to Selection on Residual Feed Intake}

The present study shows that a divergent selec- tion on RFI had commensurate effects on G:F in the 2 growth periods considered; however, the difference was amplified at the latest stage. This is in accordance with previous results of Barea et al. (2010) obtained under the fourth generation of the same selection experiment. In our study, these selection-associated differences in G:F resulted mainly from the decreased feed consumption of $\mathrm{RFI}^{-}$pigs compared with $\mathrm{RFI}^{+}$pigs, rather than to $\mathrm{ADG}$, which was similar in the 2 treatments during the postweaning period and during the growing period when adjusted for difference in BW at $67 \mathrm{~d}$ of age. Similarly, pigs of a line selected for $\mathrm{RFI}^{-}$had consumed less feed over a period of $6 \mathrm{wk}$ with a starting BW of $20 \mathrm{~kg}$ compared with a randomly selected control line (Boddicker et al., 2011b), but G:F at early stage was not affected by selection on $\mathrm{RFI}^{-}$in this aforementioned study. Moreover, in the present study, there was no RFI-associated difference in plasma IGF-I concentration assessed at the end of each test period whereas Hoque et al. (2009) using Duroc pigs found a weak genetic correlation between RFI and IGF-I concentration in the growing period from 30 to $105 \mathrm{~kg} \mathrm{BW}$. Our results are in accordance with Bunter et al. (2005) using Large White $\times$ Landrace pigs, who suggested that only juvenile IGF-I concentration (around weaning to d 35) is strongly correlated

Table 6. Nutrient and hormone plasma concentrations of pigs divergently selected on low residual feed intake $\left(\mathrm{RFI}^{-}\right)$or high residual feed intake $\left(\mathrm{RFI}^{+}\right)$and having either free access to feed or offered feed at the same level per metabolic BW (BW0.60) as RFI- pigs $\left(\mathrm{RFI}^{+\mathrm{R}}\right)$ access to feed from $67 \mathrm{~d}$ of age to slaughter ${ }^{1}$

\begin{tabular}{|c|c|c|c|c|c|}
\hline Item & $\mathrm{RFI}^{-}$ & $\mathrm{RFI}^{+}$ & $\mathrm{RFI}^{+\mathrm{R}}$ & RSD & $P$-value \\
\hline $\mathrm{N}$ & 18 & 14 & 14 & & \\
\hline \multicolumn{6}{|l|}{ Plasma nutrients, } \\
\hline Glucose, g/L & 1.2 & 1.3 & 1.2 & 0.3 & 0.78 \\
\hline Lactate, $\mathrm{mmol} / \mathrm{L}$ & 10.5 & 11.6 & 9.9 & 7.1 & 0.81 \\
\hline Proteins, g/L & 89 & 97 & 86 & 15 & 0.16 \\
\hline Urea, mmol/L & 430 & 453 & 416 & 106 & 0.64 \\
\hline$\beta-\mathrm{OH}^{2}, \mu \mathrm{mol} / \mathrm{L}$ & 45.5 & 48.3 & 53.2 & 15.2 & 0.37 \\
\hline Triglycerides, mg/L & $418^{\mathrm{a}}$ & $569^{b}$ & $481^{\mathrm{ab}}$ & 144 & 0.04 \\
\hline $\mathrm{NEFA}, \mu \mathrm{mol} / \mathrm{L}$ & 111 & 92 & 101 & 93 & 0.85 \\
\hline Albumin, $\mathrm{g} / \mathrm{L}$ & 57.0 & 56.4 & 54.5 & 9.4 & 0.76 \\
\hline \multicolumn{6}{|l|}{ Plasma hormones } \\
\hline IGF-I, ng/mL & 221 & 240 & 217 & 76 & 0.70 \\
\hline $\mathrm{TT}^{3}, \mathrm{ng} / \mathrm{mL}$ & 1.29 & 1.10 & 1.21 & 0.26 & 0.15 \\
\hline $\mathrm{TT} 4^{4}, \mathrm{ng} / \mathrm{mL}$ & $74.1^{\mathrm{b}}$ & $67.1^{\mathrm{a}}$ & $71.0^{\mathrm{ab}}$ & 9.1 & 0.10 \\
\hline Insulin, $\mu \mathrm{UI} / \mathrm{mL}$ & 38.2 & 41.7 & 36.5 & 22.3 & 0.82 \\
\hline Leptin, ng/mL & 2.80 & 2.62 & 2.57 & 0.91 & 0.76 \\
\hline \multicolumn{6}{|c|}{ a,bWithin a row, means without a common superscript differ $(P<0.10)$} \\
\hline \multicolumn{6}{|c|}{$\begin{array}{l}{ }^{1} \text { Values are least square means. RSD = residual SD (corresponding to the } \\
\text { root-mean-square error of the full ANOVA model). }\end{array}$} \\
\hline \multicolumn{6}{|c|}{${ }^{2} \beta-\mathrm{OH}=\beta$-hydroxybutyrate. } \\
\hline \multicolumn{6}{|c|}{${ }^{3} \mathrm{TT} 3=$ total triiodothyronine. } \\
\hline \multicolumn{6}{|c|}{${ }^{4} \mathrm{TT} 4=$ total thyroxin. } \\
\hline
\end{tabular}


with RFI. Besides IGF-I, IGF-II and insulin-like growth factor-binding proteins (IGFBP) should be considered in further studies for their important roles in tissue development and postnatal growth. In the present study, restricted feeding (about $90 \%$ of ad libitum) during the growing period in pigs selected for $\mathrm{RFI}^{+}$caused a slight decrease $(-11 \%)$ in ADG, but it did not affect G:F during this period and plasma IGF-I concentration at market weight. A restriction of feed intake by less than $20 \%$ is likely not enough to affect these variables, as previously described (Combes et al., 1997; Lee et al., 2002) whereas a more severe restriction $(65 \%$ of DFI) may decrease G:F (Heyer and Lebret, 2007). Importantly, modifications in lean meat content, body fat depth, and adipose tissue lipid content were manifested exclusively at commercial slaughter weight. This confirms that the magnitude of the association between body composition and variation in RFI is influenced by age and stage of maturity of the tested animals as previously suggested in beef cattle (Herd and Arthur, 2009). The novel finding of the present study is that adaptations of tissue metabolisms in response to RFI occurred in pigs; however, the differences were also mainly observed at market weight.

\section{Changes in Protein Metabolism Occurred at Short Term}

At $19 \mathrm{~kg} \mathrm{BW}$ (postweaning period), both protein synthesis rate and the specific activity of the proteasome involved in protein catabolism were decreased in the liver of $\mathrm{RFI}^{+}$pigs compared with $\mathrm{RFI}^{-}$pigs. This suggests that hepatic protein turnover might be reduced in the less efficient piglets. This might be partly related to the greatest plasma insulin concentration measured in $\mathrm{RFI}^{+}$piglets during the postprandial phase. Indeed, insulin participates together with AA to the inhibition of hepatic proteolysis (Chotechuang et al., 2011). However, insulin has generally no effect on hepatic protein synthesis, as shown in neonate piglets (Davis et al., 2001) or in growing mice (Bark et al., 1998). In addition, enzyme activities related to protein catabolism in the liver did not differ between RFI lines at commercial weight. Moreover, there was no difference in protein synthesis or proteolytic enzyme activities in the LM, irrespective of the test period. This is somewhat surprising, considering that differences in the rates of protein degradation and protein synthesis within the muscle are assumed to have a significant role in variability of energy expenditure (Herd and Arthur, 2009, for review). With the finding of a greater calpastatin activity in muscle of $\mathrm{RFI}^{-}$pigs compared with controls at $50 \mathrm{~kg} \mathrm{BW}$ (Smith et al., 2011), it is then possible that the activity of this inhibitor of proteolysis was affected in $\mathrm{LM}$ of $\mathrm{RFI}^{+}$pigs compared with $\mathrm{RFI}^{-}$pigs, which may contribute to the decreased loin proportion recorded in the carcass of the formers compared with the latter pigs at market weight. However, this deserves specific studies.

\section{Long-Term Alterations of Energy Catabolism in Tissues}

Whereas enzyme activity levels related to energy metabolism in liver and LM did not differ between $\mathrm{RFI}^{-}$ and $\mathrm{RFI}^{+}$piglets during postweaning, our study shows elevated enzyme activities for both tissues of $\mathrm{RFI}^{+}$pigs compared with $\mathrm{RFI}^{-}$pigs at market weight. Our study provides new evidence that these differences were mainly associated to a direct effect of RFI genetic divergence in the liver whereas they were more associated with selection-induced difference in daily feed consumption in the LM. One modified pathway in response to RFI selection likely concerned glucose metabolism, with the pivotal role of LDH in the cross talk between skeletal muscle and the liver. Indeed, LDH activity was found greater in $\mathrm{RFI}^{+}$ pigs than in $\mathrm{RFI}^{-}$pigs in $\mathrm{LM}$ where this enzyme is involved in the terminal anaerobic conversion of glucose into lactate as well as in the liver where this enzyme participates to the neosynthesis of glucose from lactate. These concomitant increases suggest an acceleration of the Cori cycle (Katz and Tayek, 1999) in $\mathrm{RFI}^{+}$pigs compared with $\mathrm{RFI}^{-}$pigs. This might be a way for $\mathrm{RFI}^{+}$pigs to generate ATP faster within muscle cells without adverse effects on glycemia, as illustrated by the lack of change in plasma glucose concentration between $\mathrm{RFI}^{+}$and $\mathrm{RFI}^{-}$groups. Because gluconeogenesis from lactate needs 6 nucleotide triphosphates whereas anaerobic glycolysis produces only 2 ATP from 1 molecule of glucose, this accelerated cycle involving glucose and lactate between skeletal muscle and the liver could then contribute to the greater maintenance requirements calculated for pigs selected for $\mathrm{RFI}^{+}$compared with $\mathrm{RFI}^{-}$pigs (Barea et al., 2010).

The greater activity of HAD, a key enzyme in the mitochondrial and peroxisomal fatty acid $\beta$-oxidation, in liver and $\mathrm{LM}$ of $\mathrm{RFI}^{+}$pigs compared with $\mathrm{RFI}^{-}$pigs indicates that fatty acid oxidation might be another energy metabolic pathway altered by RFI selection. There was also a greater activity of CS in the $\mathrm{LM}$ of $\mathrm{RFI}^{+}$pigs, where this first enzyme in the Krebs cycle is implicated in the conversion of acetyl CoA for ATP generation. In agreement, variation in the energetic efficiency of mitochondria previously was suggested to be associated with differences in feed efficiency (for review, see Herd and Arthur, 2009). Thus, in the liver where CS activity was similar in both RFI lines, the excess of acetyl CoA generated from the incomplete fatty acid oxidation can be converted to ketone bodies, which are exported in blood to be used as an energy source in skeletal muscles (Williamson et al., 1971). Whereas a positive correlation between RFI and plasma $\beta$-hydroxybutyrate concentrations were reported in heifers (Kelly et al., 2010), plasma $\beta$-hydroxybutyrate concentration did not differ between the 
$\mathrm{RFI}^{-}$pigs and $\mathrm{RFI}^{+}$pigs under study. In nonruminants, ketogenesis primarily takes place in fasted animals (Fernandez-Figares et al., 2004). This likely explains why plasma $\beta$-hydroxybutyrate concentrations were particularly low in the present study where blood was sampled a few hours after the last morning meal. Therefore, kinetics investigations would be helpful to determine the responses of ketone body production to RFI selection. Altogether, the decreased activities of energy-producing enzymes in the liver and LM of $\mathrm{RFI}^{-}$pigs compared with $\mathrm{RFI}^{+}$pigs support the assumption that pigs selected on $\mathrm{RFI}^{-}$require less energy to maintain a constant BW (Boddicker et al., 2011a).

Considering that thyroid hormones promote heat production and stimulate both anabolic and catabolic processes (Freake and Oppenheimer, 1995), greater plasma concentrations in thyroid hormones could have been expected in $\mathrm{RFI}^{+}$pigs compared with $\mathrm{RFI}^{-}$pigs, as described in cockerels (Gabarrou et al., 2000). However, in the present study, TT4 plasma concentration tended to be lower in those pigs compared with $\mathrm{RFI}^{-}$pigs at market weight. Similarly, Lefaucheur et al. (2011) found lower plasma concentrations of TT4 but also depressed concentrations of TT3 and free triiodothyronine (T3) in $\mathrm{RFI}^{+}$pigs compared with $\mathrm{RFI}^{-}$ pigs. Moreover, feed restriction in $\mathrm{RFI}^{+\mathrm{R}}$ pigs did not affect plasma thyroid hormone concentrations whereas caloric restriction was shown to decrease both plasma TT3 and TT4 concentrations independently of RFI status (Lkhagvadorj et al., 2010). This discrepancy may result from the difference in restriction level between the 2 experiments.

\section{Adipose Tissue Traits Associated to Differences in Carcass Fat Content}

Although numerous studies reported positive phenotypic and genetic correlations between RFI and carcass fat content in pigs in the range of 50 to $114 \mathrm{~kg} \mathrm{BW}$ (Gilbert et al., 2007; Boddicker et al., 2011a; Smith et al., 2011), the cellular and metabolic bases of these associations remain largely to be clarified. Our study first extends these findings by showing that differences in adiposity traits between $\mathrm{RFI}^{+}$ and $\mathrm{RFI}^{-}$lines at market weight disappeared when $\mathrm{RFI}^{+}$ pigs were fed the same level of feed as $\mathrm{RFI}^{-}$pigs during the growing period. Similarly, Young et al. (2011) showed that backfat content was positively correlated with daily feed intake when comparing a selection line for $\mathrm{RFI}^{-}$with a control line. In the present study, differences in backfat depth and content between $\mathrm{RFI}^{+}$and $\mathrm{RFI}^{-}$treatments were parallel to enlarged adipocytes in SCAT of $\mathrm{RFI}^{+}$pigs. However, there were no marked changes in specific activity levels of key lipogenic enzymes in SCAT and in the liver of the pigs under study. This was quite unexpected because Lkhagvadorj et al. (2010) revealed a downregulation of numerous genes participating in lipid metabolism in backfat of $\mathrm{RFI}^{-}$pigs compared with $\mathrm{RFI}^{+}$pigs. As adipocyte volume is influ- enced by the balance between lipolysis and lipogenesis, it is possible that lipolytic rate was modified in response to both RFI and feed restriction. Another explanation that may account for differences in adiposity between RFI lines could be a greater uptake of circulating lipids by adipose tissues in $\mathrm{RFI}^{+}$pigs, as we reported a greater plasma concentration in circulating triglycerides in those pigs compared with $\mathrm{RFI}^{-}$ pigs at market weight. Altogether, further research using high-throughput gene expressions and proteomic profiling on adipose tissue, liver, and muscle should be conducted to reveal other pathways associated with RFI.

Finally, although circulating leptin concentration was positively correlated with RFI in pigs (Hoque et al., 2009; Lefaucheur et al., 2011), there were no differences in leptinemia between RFI groups in the current study. We have no definitive explanation for this discrepancy because the breed and slaughtering stage were rather similar in our study and that of Lefaucheur et al. (2011) who focused on a former (fourth) generation of selection. Similarly, Lkhagvadorj et al. (2010) did not observe any modifications in leptinemia in relation to RFI in growing pigs, but they have suggested that abundance in leptin transcripts may be a more sensitive marker to evaluate feed efficiency-associated traits than serum leptin concentration. This remains to be investigated.

\section{Conclusion}

Despite immediate modification in G:F in response to RFI selection, there were no changes in carcass composition and tissue energy metabolism during the postweaning period, with the exception of decreased protein synthesis and proteolysis in the liver of piglets selected for $\mathrm{RFI}^{+}$compared with piglets selected for $\mathrm{RFI}^{-}$. At market weight, the main modifications concerned specific activity levels of energy catabolic enzymes in the liver, where they were directly associated with genetic divergence on RFI as well as in the LM where they were more related to differences in daily feed intake. Greater catabolic activities in glucose and fatty acid metabolisms in those tissues for pigs selected for $\mathrm{RFI}^{+}$ may notably generate greater ATP to sustain daily BW gain and maintenance requirements in those pigs.

\section{LITERATURE CITED}

Barea, R., S. Dubois, H. Gilbert, P. Sellier, J. van Milgen, and J. Noblet. 2010. Energy utilization in pigs selected for high and low residual feed intake. J. Anim. Sci. 88:2062-2072.

Bark, T. H., M. A. McNurlan, C. H. Lang, and P. J. Garlick. 1998. Increased protein synthesis after acute IGF-I or insulin infusion is localized to muscle in mice. Am. J. Physiol.-Endoc. M. 275:E118123.

Bass, A., D. Brdiczka, P. Eyer, S. Hofer, and D. Pette. 1969. Metabolic differentiation of distinct muscle types at the level of enzymatic organization. Eur. J. Biochem. 10:198-206.

Bazin, R., and P. Ferre. 2001. Assays of lipogenic enzymes. Methods Mol. Biol. 155:121-127. 
Boddicker, N., N. K. Gabler, M. E. Spurlock, D. Nettleton, and J. C. M. Dekkers. 2011a. Effects of ad libitum and restricted feed intake on growth performance and body composition of Yorkshire pigs selected for reduced residual feed intake. J. Anim. Sci. 89:40-51.

Boddicker, N., N. K. Gabler, M. E. Spurlock, D. Nettleton, and J. C. M. Dekkers. 2011b. Effects of ad libitum and restricted feeding on early production performance and body composition of Yorkshire pigs selected for reduced residual feed intake. Animal 5:1344-1353.

Bradford, M. M. 1976. Rapid and sensitive method for quantitation of microgram quantities of protein utilizing principle of protein-dye binding. Anal. Biochem. 72:248-254.

Bunter, K. L., S. Hermesch, B. G. Luxford, H. U. Graser, and R. E. Crump. 2005. Insulin-like growth factor-I measured in juvenile pigs is genetically correlated with economically important performance traits. Aust. J. Exp. Agr. 45:783-792.

Chotechuang, N., D. Azzout-Marniche, C. Bos, C. Chaumontet, C. Gaudichon, and D. Tome. 2011. Down-regulation of the ubiquitinproteasome proteolysis system by amino acids and insulin involves the adenosine monophosphate-activated protein kinase and mammalian target of rapamycin pathways in rat hepatocytes. Amino Acids 41:457-468

Combes, S., I. Louveau, and M. Bonneau. 1997. Moderate food restriction affects skeletal muscle and liver growth hormone receptors differently in pigs. J. Nutr. 127:1944-1949.

Daughaday, W. H., I. K. Mariz, and S. L. Blethen. 1980. Inhibition of access of bound somatomedin to membrane-receptor and immunobindings sites - A comparison of radioreceptor and radioimmunoassay of somatomedin in native and acid-ethanol-extracted serum. J. Clin. Endocrinol. Metab. 51:781-788.

Daumas, G. 2008. Taux de muscle des pièces et appréciation de la composition corporelle des carcasses. (In French.) Journées Rech. Porcine 40:61-68.

Davis, T. A., M. L. Fiorotto, P. R. Beckett, D. G. Burrin, P. J. Reeds, D. Wray-Cahen, and H. V. Nguyen. 2001. Differential effects of insulin on peripheral and visceral tissue protein synthesis in neonatal pigs. Am. J. Physiol.-Endoc. M. 280:E770-E779.

Fernandez-Figares, I., A. E. Shannon, D. Wray-Cahen, and T. J. Caperna. 2004. The role of insulin, glucagon, dexamethasone, and leptin in the regulation of ketogenesis and glycogen storage in primary cultures of porcine hepatocytes prepared from $60 \mathrm{~kg}$ pigs. Domest. Anim. Endocrinol. 27:125-140.

Folch, J., M. Lees, and G. H. S. Stanley. 1957. A simple method for the isolation and purification of total lipides from animal tissues. J. Biol. Chem. 226:497-509.

Freake, H. C., and J. H. Oppenheimer. 1995. Thermogenesis and thyroidfunction. Annu. Rev. Nutr. 15:263-291.

Gabarrou, J. F., P. A. Geraert, J. Williams, L. Ruffier, and N. Rideau. 2000. Glucose-insulin relationships and thyroid status of cockerels selected for high or low residual food consumption. Brit. J. Nutr. 83:645-651.

Gardan, D., I. Louveau, K. Van den Maagdenberg, N. Buys, S. De Smet, and F. Gondret. 2006. Cellular and biochemical features of skeletal muscle and subcutaneous adipose tissue in pigs differing in IGF-II genotype. J. Anim. Sci. 84(Suppl.):S145(Abstr.).

Gilbert, H., J. P. Bidanel, J. Gruand, J. C. Caritez, Y. Billon, P. Guillouet, H. Lagant, J. Noblet, and P. Sellier. 2007. Genetic parameters for residual feed intake in growing pigs, with emphasis on genetic relationships with carcass and meat quality traits. J. Anim. Sci. 85:3182-3188.

Hamard, A., B. Sève, and N. Le Floc'h. 2009. A moderate threonine deficiency differently affects protein metabolism in tissues of earlyweaned piglets. Comp. Biochem. Phys. A 152:491-497.

Herd, R. M., and P. F. Arthur. 2009. Physiological basis for residual feed intake. J. Anim. Sci. 87:E64-E71.

Heyer, A., and B. Lebret. 2007. Compensatory growth response in pigs: Effects on growth performance, composition of weight gain at carcass and muscle levels, and meat quality. J. Anim. Sci. 85:769-778.

Hoque, M. A., K. Katoh, and K. Suzuki. 2009. Genetic associations of residual feed intake with serum insulin-like growth factor-I and leptin concentrations, meat quality, and carcass cross sectional fat area ratios in Duroc pigs. J. Anim. Sci. 87:3069-3075.

Jamin, A., B. Seve, J.-N. Thibault, and N. Floc'h. 2012. Accelerated growth rate induced by neonatal high-protein milk formula is not supported by increased tissue protein synthesis in low-birth-weight piglets. J. Nutr. Metab. 2012:545341.

Katz, J., and J. A. Tayek. 1999. Recycling of glucose and determination of the Cori cycle and gluconeogenesis. Am. J. Physiol.-Endoc. M. 277:E401-E407.

Kelly, A. K., M. McGee, D. H. Crews, A. G. Fahey, A. R. Wylie, and D. A. Kenny. 2010. Effect of divergence in residual feed intake on feeding behavior, blood metabolic variables, and body composition traits in growing beef heifers. J. Anim. Sci. 88:109-123.

Lee, C. Y., H. P. Lee, J. H. Jeong, K. H. Baik, S. K. Jin, J. H. Lee, and S. H. Sohnt. 2002. Effects of restricted feeding, low-energy diet, and implantation of trenbolone acetate plus estradiol on growth, carcass traits, and circulating concentrations of insulin-like growth factor (IGF)-I and IGF-binding protein-3 in finishing barrows. J. Anim. Sci. 80:84-93.

Lefaucheur, L., B. Lebret, P. Ecolan, I. Louveau, M. Damon, A. Prunier, Y. Billon, P. Sellier, and H. Gilbert. 2011. Muscle characteristics and meat quality traits are affected by divergent selection on residual feed intake in pigs. J. Anim. Sci. 89:996-1010.

Lkhagvadorj, S., L. Qu, W. G. Cai, O. P. Couture, C. R. Barb, G. J. Hausman, D. Nettleton, L. L. Anderson, J. C. M. Dekkers, and C. K. Tuggle. 2010. Gene expression profiling of the short-term adaptive response to acute caloric restriction in liver and adipose tissues of pigs differing in feed efficiency. Am. J. Physiol.-Regul. Integr. Comp. Physiol. 298:R494-R507.

Louveau, I., and M. Bonneau. 1996. Effect of a growth hormone infusion on plasma insulin-like growth factor-I in Meishan and Large White pigs. Reprod. Nutr. Dev. 36:301-310.

Matte, J. J. 1999. A rapid and non-surgical procedure for jugular catheterization of pigs. Lab. Anim. 33:258-264.

Qian, H., C. R. Barb, M. M. Compton, G. J. Hausman, M. J. Azain, R. R. Kraeling, and C. A. Baile. 1999. Leptin mRNA expression and serum leptin concentrations as influenced by age, weight, and estradiol in pigs. Domest. Anim. Endocrinol. 16:135-143.

Richardson, E. C., and R. M. Herd. 2004. Biological basis for variation in residual feed intake in beef cattle. 2. Synthesis of results following divergent selection. Aust. J. Exp. Agr. 44:431-440.

Smith, R. M., N. K. Gabler, J. M. Young, W. Cai, N. J. Boddicker, M. J. Anderson, E. Huff-Lonergan, J. C. M. Dekkers, and S. M. Lonergan. 2011. Effects of selection for decreased residual feed intake on composition and quality of fresh pork. J. Anim. Sci. 89:192-200.

Srere, P. A. 1969. Citrate synthase. [EC 4.1.3.7. Citrate oxaloacetate-lyase (CoA-acetylating)]. Pages 3-11 in M. L. John, ed. Methods in Enzymology, vol. 13. Academic Press, New York, N.

Vassault, A. 1983. Lactate dehydrogenase: UV-method with pyruvate and NADH. Pages 118-126 in Methods of Enzymatic Enzymology, vol. 3. Verlag Chemie, Weinheim, Germany.

Williamson, D. H., M. W. Bates, M. A. Page, and H. A. Krebs. 1971. Activities of enzymes involved in acetoacetate utilization in adult mammalian tissues. Biochem. J. 121:41-47.

Young, J. M., W. Cai, and J. C. M. Dekkers. 2011. Effect of selection for residual feed intake on feeding behavior and daily feed intake patterns in Yorkshire swine. J. Anim Sci. 89:639-647. 
References

Citations

This article cites 34 articles, 14 of which you can access for free at: http://www.journalofanimalscience.org/content/90/13/4771\#BIBL

This article has been cited by 3 HighWire-hosted articles: http://www.journalofanimalscience.org/content/90/13/4771\#otherarticles 